\section{Water Relations of Various Peach Cultivars in Relation to Peach Canker Disease}

\author{
A.R. Biggs \\ West Virginia University, University Experiment Farm, P.O. Box 609, \\ Kearneysville, WV 25430 \\ Additional index words. Prunus persica, suberin, Leucostoma spp.
}

\begin{abstract}
Whole-shoot water potential, osmotic potential of the xylem fluid, and bark water potential were examined from late winter through early spring for six peach [Prunus persica (L.) Batsch.] cultivars varying in relative susceptibility to Leucostoma canker. There were significant differences among cultivars for whole-shoot water potential on all 11 dates tested in 1986, but not in $\mathbf{1 9 8 5}$. The date effect was not consistent among cultivars, although when averaged across dates, the whole-shoot water potential of 'Loring' was significantly more negative than that of 'Candor' or 'Garnet Beauty'. There were significant differences among cultivars for xylem fluid osmotic potential on one of five dates tested in 1985 and three of 11 dates tested in 1986, although cultivar differences were not consistent between years. Cultivars exhibited differences in bark water potential on three of five dates tested in 1985, with 'Loring' exhibiting the least negative values when averaged across dates. There were only occasional significant correlations of the water status characteristics with relative susceptibility to Leucostoma canker or suberin accumulation. Measurements of plant water status among cultivars or genotypes in peach do not appear to be reliable indicators of susceptibility to Leucostoma spp. or wound response.
\end{abstract}

Peach canker, a fungal disease caused by Leucostoma cincta (Pers. ex Fr.) Höhn. [anamorph $=$ Leucocytospora cincta (Sacc.) Höhn.] and L. persoonii (Nits.) Höhn. [anamorph $=$ L. leucostoma (Pers.) Höhn.], is a major limiting factor in peach production in northern North America. The disease is initiated in wounds created by pruning, leaf abscission, cold injury, and insect damage (Willison, 1936). Symptoms include perennial cankers on trunks, scaffold limbs, and branches; crop losses occur mainly through reduction in bearing surface and premature tree death. All the currently grown peach cultivars are susceptible to these pathogens (Scorza, 1982), and there is no known treatment that will prevent infection over the long term (Biggs, 1989b). However, some varietal differences in the degree and severity of infection exist (Weaver, 1963 ).

Studies of Leucostoma canker in prune in California (Bertrand et al., 1976) have shown that water deficit is associated with disease incidence. Previous research with peach (Biggs and Cline, 1986) revealed that 'Candor' formed wound periderm and suberin (characters associated with resistance to Leucostoma spp.) more quickly under irrigation than in nonirrigated plots. However, 'Redhaven' did not respond to irrigation treatments, suggest-

Received for publication 1 Feb. 1993. Accepted for publication 22 Apr. 1993. This research was conducted while A.R.B. was a research scientist at Agriculture Canada, Research Station, Vineland Station, Ont., Canada. Appreciation is extended to Ann Curwin for technical assistance. The cost of publishing this paper was defrayed in part by the payment of page charges. Under postal regulations, this paper therefore must be hereby marked advertisement solely to indicate this fact. in the 1984 planting: 'Sunhaven', 'Redhaven', 'Garnet Beauty', 'Loring', and 'Vanity'; 'Candor' was added in 1985. Soils are imperfectly drained Vineland fine sandy loam and are typical of peach orchard soils in the Niagara Peninsula. The orchard was established in randomized complete blocks with l-year-old, virus-tested, 'canker-free nursery stock on Bailey rootstock. Tree spacing was 1.5 x $4.0 \mathrm{~m}$. The orchard was managed with clean cultivation in the spring followed by a ryegrass cover crop planted in July. Fungicides and insecticides were applied as needed to control peach leaf curl, brown rot, and oriental fruit moth [ferric dimethyldithiocarbamate (ferbam), cis$N$-trichloromethylthio-4-cyclohexene- 1,2diocarboximide (captan), and O,O-dimethylphosphorodithioate $\mathrm{S}$ ester with $N$ (mercaptomethyl)phthalimide (phosmet), respectively]. The cultivars listed in the tables were selected to represent a range of susceptibility to Leucostoma spp. based on historical field performance ratings with visual assessment and a 1 to 10 numerical rating system (Biggs and Miles, 1988; R.E.C. Layne, personal communication). None of the cultivars selected for these experiments was immune to the pathogens because known sources of immunity are not available. Therefore, the cultivars selected ranged from moderately resistant to highly susceptible in the following order: 'Sunhaven', 'Redhaven', 'Garnet Beauty', 'Loring', 'Vanity', and 'Candor'. The six cultivars also were compared for their relative suberin accumulation capacity following mechanical wounding in relation to their relative water status. Data on suberin accumulation and methodology have been reported by Biggs and Miles (1988); however, values from May in both years were used in this study to examine their correlation with the measured water relations characteristics. The study was conducted in late winter and early spring because this is a critical period for infection and enlargement of existing cankers.

Water relations measurements. All water relations measurements were conducted in one block of the planting from 0830 to $1130 \mathrm{HR}$ on trees that had been established in the orchard for $\geq 1$ year. The water status of shoots was determined with a pressure bomb (PMS, Agriculture Canada experimental farm in Jordan Station, Ont. Five cultivars were included

Table 1. Mean pressure bomb readings and correlations to relative susceptibility to Leucostoma canker and suberin accumulation from five peach cultivars during late Winter to early Spring 1985.

\begin{tabular}{|c|c|c|c|c|c|c|}
\hline \multirow[b]{2}{*}{ Cultivars (rank) ${ }^{z}$} & \multicolumn{6}{|c|}{ Water potential (MPa) } \\
\hline & 19 Mar. & 1 Apr. & $15 \mathrm{Apr}$. & 30 Apr. & $13 \mathrm{May}$ & Means \\
\hline Sunhaven (1) & $-1.11 a^{y}$ & $-0.70 \mathbf{a}$ & $-0.63 \mathrm{a}$ & $-0.79 a$ & $-1.54 \mathrm{a}$ & $-0.96 \mathrm{a}$ \\
\hline Redhaven (2) & $-1.12 \mathrm{a}$ & $-0.92 \mathbf{a}$ & $-0.85 \mathrm{a}$ & $-0.83 \mathrm{a}$ & $-1.33 \mathrm{a}$ & $-1.01 \mathrm{a}$ \\
\hline Garnet Beauty (3) & $-1.20 \mathrm{a}$ & $-0.79 \mathrm{a}$ & $-0.74 \mathrm{a}$ & $-0.76 \mathrm{a}$ & $-1.28 \mathrm{a}$ & $-0.96 \mathrm{a}$ \\
\hline Loring (4) & $-1.04 \mathrm{a}$ & -0.89 a & $-0.68 \mathrm{a}$ & $-0.76 \mathrm{a}$ & $-1.33 \mathbf{a}$ & $-0.95 \mathrm{a}$ \\
\hline Vanity (5) & $-1.12 \mathrm{a}$ & $-0.70 \mathbf{a}$ & $-0.78 \mathrm{a}$ & $-0.87 \mathrm{a}$ & $-1.27 \mathrm{a}$ & $-0.94 \mathrm{a}$ \\
\hline Means & $-1.12 b$ & $-0.81 \mathrm{c}$ & $-0.74 \mathrm{c}$ & $-0.80 \mathrm{c}$. & $-1.36 \mathbf{a}$ & -0.97 \\
\hline Canker $r_{s}^{x}$ & $-0.05^{\mathrm{Ns}}$ & $0.10^{\text {NS }}$ & $-0.30^{\mathrm{Ns}}$ & $-0.15^{\mathrm{NS}}$ & $0.97^{0.005}$ & $0.79^{0.1}$ \\
\hline Suberin $r_{s}{ }^{x}$ & $-0.05^{\mathrm{Ns}}$ & $0.31^{\mathrm{NS}}$ & $0.0^{\mathrm{Ns}}$ & $-0.56^{\mathrm{NS}}$ & $-0.61^{\mathrm{Ns}}$ & $-0.58^{\mathrm{Ns}}$ \\
\hline
\end{tabular}

${ }^{2}$ Numbers in parentheses are the cultivar ranks for relative susceptibility to Leucostoma canker $(1=$ least susceptible, $5=$ most susceptible).

Each value is the mean of five replicate pressure bomb measurements. Letters in columns denote significant differences according to Duncan's multiple range test $(P \leq 0.05)$, except for date means where letters in the row denote significant differences.

'Values are the Spearman's nonparametric rank correlation coefficient with the probability of significance as the superscript (NS = not significant). 
Table 2. Mean pressure bomb readings and correlations to relative susceptibility to Leucostoma canker and suberin accumulation from six peach cultivars during late Winter to early Spring 1986.

\begin{tabular}{|c|c|c|c|c|c|c|c|c|c|c|c|c|}
\hline \multirow[b]{2}{*}{ Cultivar (rank) ${ }^{z}$} & \multicolumn{12}{|c|}{ Water potential (MPa) } \\
\hline & 12 Feb. & 19 Feb. & 26 Feb. & 5 Mar. & 12 Mar. & 19 Mar. & 25 Mar. & 2 Apr. & 9 Apr. & 17 Apr. & 22 Apr. & Mean \\
\hline Sunhaven (1) & $-1.30 b^{y}$ & $-2.48 b$ & $-1.13 b$ & $-1.00 \mathrm{a}$ & $-0.63 b c$ & $-0.51 \mathrm{bc}$ & $-0.65 b c$ & $-0.49 b$ & $-0.61 \mathrm{ab}$ & $-0.43 a b c$ & $-0.79 c$ & $-0.69 \mathrm{ab}$ \\
\hline Redhaven (2) & $-1.56 a$ & $-4.32 \mathrm{a}$ & $-1.39 a \bar{b}$ & $-0.84 a b$ & $-0.63 \mathrm{bc}$ & $-0.52 b c$ & $-0.65 b c$ & $-0.50 \mathrm{~b}$ & $-0.57 \mathrm{ab}$ & $-0.39 \mathrm{bc}$ & $-0.99 \mathrm{a}$ & $-0.70 \mathrm{ab}$ \\
\hline Garnet Beauty (3) & $-0.98 \mathrm{c}$ & $-2.00 b$ & $-1.06 \mathrm{~b}$ & $-0.79 a b$ & $-0.73 \mathrm{ab}$ & $-0.57 b$ & $-0.51 \mathrm{c}$ & $-0.51 b$ & $-0.57 a b$ & $-0.36 c$ & $-0.91 a b$ & $-0.66 b$ \\
\hline Loring (4) & $-1.27 \mathbf{b}$ & $-2.36 b$ & $-1.47 \mathrm{a}$ & $-0.74 b$ & $-0.68 \mathrm{abc}$ & $-0.48 \mathrm{c}$ & $-0.60 \mathrm{bc}$ & $-0.67 \mathrm{a}$ & $-0.63 \mathrm{a}$ & $-0.45 \mathrm{ab}$ & $-0.79 c$ & $-0.74 \mathrm{a}$ \\
\hline Vanity (5) & $-1.10 b c$ & $-1.96 \mathrm{~b}$ & $-1.23 b$ & $-0.92 \mathrm{ab}$ & $-0.78 \mathbf{a}$ & $-0.66 \mathrm{a}$ & $-1.00 \mathrm{a}$ & $-0.54 b$ & $-0.60 \mathrm{ab}$ & $-0.47 \mathrm{a}$ & $-0.83 b c$ & $-0.70 \mathrm{ab}$ \\
\hline Candor (6) & $-1.18 b c$ & $-1.86 b$ & $-1.24 b$ & $-0.79 a b$ & $-0.58 \mathrm{c}$ & $-0.52 b c$ & $-0.72 b$ & $-0.54 b$ & $-0.54 \mathrm{~b}$ & $-0.42 \mathrm{abc}$ & $-0.77 \mathrm{c}$ & $-0.68 \mathrm{~b}$ \\
\hline Means & $-1.23 \mathrm{a}$ & $-2.51 \mathrm{f}$ & $-1.25 \mathrm{a}$ & $-0.85 b$ & $-0.67 c$ & $-0.66 \mathrm{~d}$ & $-0.68 \mathrm{c}$ & $-0.54 \mathrm{~d}$ & $-0.58 \mathrm{~d}$ & $-0.42 \mathrm{e}$ & $-0.84 b$ & -0.70 \\
\hline Canker $r_{s}^{x}$ & $0.54^{\mathrm{Ns}}$ & $0.89^{0.01}$ & $-0.26^{\mathrm{NS}}$ & $0.46^{\mathrm{NS}}$ & $-0.03^{\mathrm{Ns}}$ & $-0.43^{\mathrm{Ns}}$ & $-0.49^{\text {Ns }}$ & $-0.83^{0.05}$ & $0.37^{\mathrm{Ns}}$ & $-0.31^{\mathrm{NS}}$ & $0.46^{\mathrm{Ns}}$ & $0.0^{\mathrm{ss}}$ \\
\hline Suberin $r_{s}{ }^{x}$ & $0.14^{\text {Ns }}$ & $-0.31^{\mathrm{Ns}}$ & $0.82^{004}$ & $-0.49^{\mathrm{Ns}}$ & $-0.20^{\mathrm{Na}}$ & $-0.31^{\mathrm{Ns}}$ & $0.37^{\mathrm{Ns}}$ & $0.83^{0.05}$ & $0.25^{\mathrm{ss}}$ & $0.60^{\text {Ns }}$ & $0.55^{\mathrm{ss}}$ & $0.64^{\mathrm{Ns}}$ \\
\hline
\end{tabular}

${ }^{2}$ Numbers in parentheses are the cultivar ranks for relative susceptibility to Leucostoma canker ( $1=$ least susceptible, $5=$ most susceptible).

'Each value is the mean of five replicate pressure bomb measurements. Letters in columns denote significant differences according to Duncan's multiple range test $(P \leq 0.05)$, except for date means where letters in the row denote significant differences.

'Values are the Spearman's nonparametric rank correlation coefficient with the probability of significance as the superscript (Ns = not significant).

Corvallis, Ore.). Five terminal shoots (one from each tree), $\approx 12$ to $15 \mathrm{~cm}$ long and from a particular cultivar, were selected from the tree perimeter, placed in a plastic bag, and brought into the laboratory ( $\approx 25 \mathrm{~m}$ from the orchard). Shoots from the next randomly selected cultivar to be examined were collected from the field as the last replicate of the previous cultivar was being tested in the laboratory. Shoot water status was read from the instrument at the first appearance of liquid at the cut end of the shoot xylem.

The xylary fluid exuding from the cut end of each shoot was absorbed onto filter paper disks and this was placed immediately into a Wescor C-52 sample chamber (Wescor Corp., Logan, Utah) for determination of xylem sap osmotic potential with a Wescor HR-33 microvolt meter. Xylem sap samples were equilibrated for $5 \mathrm{~min}$, and osmotic potential was determined with the dewpoint method.

The water potential of bark from l-yearold shoots was determined with the Wescor instrumentation. Bark disks, $\approx 6 \mathrm{~mm}$ in diameter, from three replicate shoots per cultivar were removed from freshly cut shoots with a sharpened cork borer, placed immediately in the sample chambers, equilibrated for $30 \mathrm{~min}$ (time determined in preliminary trials), and the water potential determined with the psychrometric method. Sample chambers were calibrated with standard solutions at the be-

ginning and end of each day during which the above experiments were conducted.

Experiments were conducted on five dates in 1985 [20 Mar.; 2, 16, and 29 Apr. (budbreak); and 14 May], and 11 dates in 1986 [ 12, 19, and 26 Feb.; 5, 12, 19, and 26 Mar.; 2, 9, 17 (budbreak), and 22 Apr.].

Statistical analyses. Analysis of variance (ANOVA) was performed at each date to determine the cultivar effect for the various water relations attributes (GLM procedure; SAS, Cary, N.C.). After means were separated with Duncan's multiple range test, each cultivar was ranked from 1 to 6 (most negative to least negative) for each of the water relations factors. These ranks were compared to the cultivar ranks of field susceptibility to the peach canker disease $(1=$ least susceptible, 6 $=$ most susceptible) with Spearman's rank correlation procedure (CORR procedure, Spearman option; SAS) (Steel and Torrie, 1980). At the end of each year, the data were subjected to a two-factor ANOVA to determine trends in water relations by date and cultivar.

Whole-shoot water status. In 1985, from 19 Mar. through 13 May, the pressure bomb detected no significant cultivar differences in plant moisture status (Table 1). The effect of date was significant $(P \leq 0.05)$, however, with shoots exhibiting increased moisture as they emerged from dormancy during April. A pro-

Table 3. Mean osmotic potential of xylem sap fluid and correlations to relative susceptibility to Leucostoma canker and suberin accumulation from six peach cultivars during late Winter to early Spring 1985.

\begin{tabular}{|c|c|c|c|c|c|c|}
\hline \multirow[b]{2}{*}{ Cultivars (rank) ${ }^{z}$} & \multicolumn{6}{|c|}{ Osmotic potential (MPa) } \\
\hline & $19 \mathrm{Mar}$. & 1 Apr. & 15 Apr. & 30 Apr. & $13 \mathrm{May}$ & Means \\
\hline Sunhaven (1) & $-1.01 \mathrm{a}^{y}$ & $-0.90 \mathrm{c}$ & $-1.19 \mathrm{a}$ & -0.91 a & $-1.02 \mathrm{a}$ & $-1.01 \mathrm{a}$ \\
\hline Redhaven (2) & $-1.03 \mathrm{a}$ & $-1.80 \mathrm{a}$ & $-1.34 \mathrm{a}$ & $-1.05 \mathrm{a}$ & $-0.91 \mathrm{a}$ & $-1.23 \mathrm{a}$ \\
\hline Garnet Beauty (3) & $-1.07 \mathrm{a}$ & $-1.00 b c$ & $-1.23 \mathrm{a}$ & $-1.18 \mathrm{a}$ & $-0.94 \mathrm{a}$ & $-1.09 \mathrm{a}$ \\
\hline Loring (4) & $-1.11 \mathrm{a}$ & $-1.72 a b$ & $-1.32 \mathrm{a}$ & $-0.84 \mathrm{a}$ & $-0.91 \mathrm{a}$ & $-1.19 \mathrm{a}$ \\
\hline Vanity (5) & $-1.03 \mathrm{a}$ & $-1.13 \mathrm{abc}$ & $-1.20 \mathrm{a}$ & $-1.09 \mathrm{a}$ & $-1.15 \mathrm{a}$ & $-1.12 \mathrm{a}$ \\
\hline Means & $-1.05 b c$ & $-1.31 \mathrm{a}$ & $-1.26 \mathrm{ab}$ & $-1.01 \mathrm{c}$ & $-0.98 \mathrm{c}$ & -1.13 \\
\hline Canker $r_{s}^{x}$ & $-0.56^{\mathrm{Ns}}$ & $-0.30^{\mathrm{Ns}}$ & $-0.30^{\mathrm{vs}}$ & $-0.20^{\mathrm{Ns}}$ & $-0.21^{\mathrm{Ns}}$ & $-0.30^{\mathrm{Ns}}$ \\
\hline Suberin $r_{s}{ }^{x}$ & $0.97^{0.005}$ & $0.30^{\mathrm{ss}}$ & $0.40^{\mathrm{Ns}}$ & $0.0^{\mathrm{Ns}}$ & $-0.36^{\mathrm{Ns}}$ & $0.30^{\mathrm{Ns}}$ \\
\hline
\end{tabular}

${ }^{2}$ Numbers in parentheses are the cultivar ranks for relative susceptibility to Leucostoma canker ( $1=$ least susceptible, $5=$ most susceptible)

${ }^{y}$ Each value is the mean of five replicate measurements of the xylary fluid extruded during the pressure bomb procedure. Osmotic potential was determined with the dewpoint method. Letters in columns denote significant differences according to Duncan's multiple range test $(P \leq 0.05)$, except for date means where letters in the row denote significant differences.

'Values are the Spearman's nonparametric rank correlation coefficient with the probability of significance as the superscript (NS = not significant). longed period without rainfall from mid-April through mid-May was probably responsible for the significant decrease in pressure bomb values on 13 May relative to the April values (Table 1). There was a significant correlation $(r=0.97, P \leq 0.005)$ between pressure bomb values and relative susceptibility to Leucostoma spp. in May (and with the mean values over time), but not with the other dates. The more resistant cultivars exhibited increasingly negative water status (Table 1). In May, the pressure bomb did not detect plant water status that would correlate with suberin accumulation.

In 1986, variation among cultivars in pressure bomb readings was readily apparent at each of the 11 dates, although there was little pattern in the observed variation (Table 2). In general, two of the three cultivars most susceptible to Leucostoma spp., 'Loring' and 'Candor', exhibited the most negative pressure bomb values on seven of the 11 dates. This appears to contrast with the 1985 findings; however, water stress due to lack of rainfall was not a factor in 1986, as it was in May 1985. Occasionally, significant correlations of pressure bomb values with relative susceptibility and suberin accumulation were observed in 1986. On 19 Feb., the most resistant cultivars exhibited the most negative pressure bomb values, although this correlation reversed on $2 \mathrm{Apr}$., when the most susceptible cultivars exhibited the most negative values (Table 2). For suberin, on nine of 11 dates, there was no correlation with pressure bomb readings. On 26 Feb. and 2 Apr., the cultivars with the most negative pressure bomb values also exhibited the least suberin accumulation when stems were wounded later in May. Although one would expect such a relationship based on previous findings (Bertrand et al., 1976; Biggs and Cline, 1986), the reasons for significant correlations of water status in February and April with suberin accumulation in May are not easily explained and, indeed, could be due to the random alignment of ranks when few cultivars are employed. The lack of correlation on nine of 11 dates is probably the more significant finding.

Xylary fluid osmotic potential. Osmotic potential of the xylary fluid in 1985 tended to become less negative with time and as the trees emerged from dormancy. Osmotic potential 
Table 4. Mean osmotic potential of xylem sap fluid and correlations to relative susceptibility to Leucostoma canker and suberin accumulation from six peach cultivars during late Winter to early Spring 1986.

\begin{tabular}{|c|c|c|c|c|c|c|c|c|c|c|c|}
\hline \multirow[b]{2}{*}{ Cultivar (rank) ${ }^{2}$} & \multicolumn{11}{|c|}{ Osmotic potential (MPa) } \\
\hline & 19 Feb. & 26 Feb. & 5 Mar. & 12 Mar. & 19 Mar. & 25 Mar. & 2 Apr. & 9 Apr. & 17 Apr. & 22 Apr. & Means \\
\hline Sunhaven (1) & $-7.29 \mathrm{a}^{\mathrm{y}}$ & $-1.23 \mathrm{a}$ & $-0.88 \mathrm{~b}$ & $-0.87 \mathrm{a}$ & $-0.75 \mathrm{a}$ & $-0.78 \mathrm{a}$ & $-0.58 \mathrm{a}$ & $-0.88 \mathrm{a}$ & $-0.66 \mathrm{a}$ & $-0.79 a$ & $-0.81 b c$ \\
\hline Redhaven (2) & $-6.20 a$ & $-1.24 \mathrm{a}$ & $-1.34 \mathrm{ab}$ & $-0.70 a$ & $-0.63 \mathrm{ab}$ & $-0.58 \mathrm{a}$ & $-0.58 \mathrm{a}$ & $-0.83 \mathrm{a}$ & $-0.79 \mathrm{a}$ & $-0.92 \mathrm{a}$ & $-0.78 c$ \\
\hline Garnet Beauty (3) & $-7.06 \mathrm{a}$ & $-1.66 \mathrm{a}$ & $-1.43 \mathrm{a}$ & $-0.81 \mathrm{a}$ & $-0.60 \mathrm{ab}$ & $-0.81 \mathrm{a}$ & $-0.54 \mathrm{a}$ & $-0.91 \mathrm{a}$ & $-0.76 a$ & $-0.75 \mathrm{a}$ & $-0.93 \mathbf{a}$ \\
\hline Loring (4) & $-7.14 \mathrm{a}$ & $-1.75 \mathrm{a}$ & $-1.26 a b$ & $-0.77 \mathrm{a}$ & $-0.76 \mathrm{a}$ & $-0.61 \mathrm{a}$ & $-0.66 \mathrm{a}$ & $-0.80 \mathrm{ab}$ & $-0.75 \mathrm{a}$ & $-0.89 \mathrm{a}$ & $-0.88 \mathrm{ab}$ \\
\hline Vanity (5) & $-6.00 \mathrm{a}$ & $-1.62 \mathrm{a}$ & $-1.47 \mathrm{a}$ & $-0.73 \mathrm{a}$ & $-0.65 a b$ & $-0.77 \mathbf{a}$ & $-0.69 \mathrm{a}$ & $-0.96 a$ & $-0.79 a$ & $-0.99 a$ & $-0.88 a b$ \\
\hline Candor (6) & $-6.18 \mathrm{a}$ & $-1.45 \mathrm{a}$ & $-1.09 a b$ & $-0.68 \mathrm{a}$ & $-0.54 b$ & $-0.68 \mathbf{a}$ & $-0.64 \mathrm{a}$ & $-0.63 \mathrm{~b}$ & $-0.71 \mathrm{a}$ & $-0.90 \mathrm{a}$ & $-0.80 \mathrm{bc}$ \\
\hline Mcans & -6.66 & $-1.49 \mathbf{a}$ & $-1.24 \mathrm{~b}$ & $-0.76 \mathrm{cde}$ & 0.66 ef & $0.70 \mathrm{ef}$ & $-0.62 \mathrm{f}$ & $-0.84 \mathrm{~cd}$ & $-0.75 \mathrm{de}$ & $-0.87 \mathrm{c}$ & -0.85 \\
\hline Canker $\mathbf{r}_{\mathbf{s}}{ }^{\mathbf{x}}$. & $-0.71^{\mathrm{Ns}}$ & $0.49^{\mathrm{Ns}}$ & $0.26^{\mathrm{Ns}}$ & $-0.66^{\mathrm{Ns}}$ & $-0.37^{\mathrm{Ns}}$ & $-0.14^{\mathrm{NS}}$ & $0.60^{\mathrm{ss}}$ & $-0.26^{\mathrm{Ns}}$ & $0.20^{\mathrm{Ns}}$ & $0.43^{\mathrm{NS}}$ & $0.12^{\mathrm{Ns}}$ \\
\hline Suberin $r_{s}{ }^{x}$ & $0.26^{\mathrm{Ns}}$ & $-0.37^{\text {Ns }}$ & $0.14^{\mathrm{Ns}}$ & $0.54^{\mathrm{Ns}}$ & $-0.26^{\mathrm{Ns}}$ & $0.66^{\mathrm{Ns}}$ & $-0.77^{0.07}$ & $0.60^{\text {ss }}$ & $0.03^{\mathrm{Ns}}$ & $-0.49^{\mathrm{NS}}$ & $0.20^{\mathrm{Ns}}$ \\
\hline
\end{tabular}

${ }^{2}$ Numbers in parentheses are the cultivar ranks for relative susceptibility to Leucostoma canker $(1=$ least susceptible, $5=$ most susceptible).

${ }^{y}$ Each value is the mean of five replicate measurements of the xylary fluid extruded during the pressure bomb procedure. Osmotic potential was determined with the dewpoint method. Letters in columns denote significant differences according to Duncan's multiple range test ( $P \leq 0.05$ ), except for date ineans where letters in the row denote significant differences.

${ }^{x}$ Values are the Spearman's nonparametric rank correlation coefficient with the probability of significance as the superscript (NS = not significant).

of the xylary fluid in 1985 exhibited significant cultivar variation on only one of the five dates examined (Table 3 ). There was no correlation of xylary fluid osmotic potential with the relative susceptibility of the cultivars to Leucostoma spp. There was no correlation of xylary fluid osmotic potential with suberin accumulation in May on four of five dates examined. However, on 19 Mar., those cultivars with the most negative values for osmotic potential showed the least suberin accumulation when wounded in May.

As in 1985, the osmotic potential of the xylary fluid in 1986 tended to become less negative as the trees emerged from dormancy, although a slight increase was noted during the period from 9 to 22 Apr., and was associated developmentally with the weeks preceding, during, and following budbreak (Table 4). Cultivar differences in xylary fluid osmotic potential were apparent on three of the 11 dates tested in 1986 (Table 4). No patterns or trends based on cultivar variation could be discerned from these data, and it appears that this character does not vary significantly in relation to genetic differences among cultivars. No correlations with suberin were observed except for the data collected on 2 Apr., when those cultivars with more negative osmotic potential accumulated the least suberin.

Table 5. Mean water potential of bark tissues from six peach cultivars during late Winter to early Spring 1985.

\begin{tabular}{|c|c|c|c|c|c|c|}
\hline \multirow[b]{2}{*}{ Cultivars (rank) ${ }^{x}$} & \multicolumn{6}{|c|}{ Water potential (MPa) } \\
\hline & 19 Mar. & 1 Apr. & 15 Apr. & 30 Apr. & 13 May & Means \\
\hline Sunhaven (1) & $-5.76 \mathrm{a}^{\mathrm{y}}$ & $-4.68 \mathrm{a}$ & $-4.48 \mathrm{a}$ & $-2.99 a$ & $-3.41 b$ & $-4.27 \mathrm{ab}$ \\
\hline Redhaven (2) & $-5.49 a b$ & $-4.19 b$ & $-4.39 a$ & $-2.94 \mathrm{a}$ & $-3.56 a b$ & $-4.11 b$ \\
\hline Garnet Beauty (3) & $-5.21 b$ & $-4.80 a$ & $-4.49 a$ & $-3.08 \mathrm{a}$ & $-3.51 a b$ & $-4.25 a b$ \\
\hline Loring (4) & $-4.61 \mathrm{c}$ & $-4.32 b$ & $-4.26 \mathrm{a}$ & $-2.75 \mathrm{a}$ & $-3.47 a b$ & $-3.90 c$ \\
\hline Vanity (5) & $-5.51 \mathrm{ab}$ & $-4.50 \mathrm{ab}$ & $-4.52 \mathrm{a}$ & $-3.02 \mathrm{a}$ & $-3.81 \mathrm{a}$ & $-4.28 \mathrm{a}$ \\
\hline Means & $-5.32 \mathrm{a}$ & $-4.50 b$ & $-4.43 b$ & $-2.96 \mathrm{~d}$ & $-3.55 c$ & -4.16 \\
\hline Canker $\mathbf{r}_{\mathrm{s}}^{\mathbf{x}}$ & $0.40^{N S}$ & $0.10^{\text {ws }}$ & $-0.30^{\mathrm{NS}}$ & $-0.10^{\text {ws }}$ & $-0.60^{\mathrm{Ns}}$ & $-0.10^{\mathrm{Ns}}$ \\
\hline Suberin $r_{s}^{x}$ & $-0.90^{0.04}$ & $0.0^{\text {NS }}$ & $-0.20^{\mathrm{NS}}$ & $-0.10^{\mathrm{Ns}}$ & $0.10^{\mathrm{Ns}}$ & $-0.50^{\mathrm{Ns}}$ \\
\hline
\end{tabular}

${ }^{2}$ Numbers in parentheses are the cultivar ranks for relative susceptibility to Leucostoma canker ( $1=$ least susceptible, $5=$ most susceptible).

${ }^{y}$ Each value is the mean of five replicate measurements from 6-mm-diameter excised bark disks equilibrated for $30 \mathrm{~min}$ in a chamber hygrometer. Values less than -4.0 were determined with the psychrometric method; all other values were determined with the dewpoint method. Letters in columns denote significant differences according to Duncan's multiple range test $(P \leq 0.05)$, except for date means where letters in the row denote significant differences.

"Values are the Spearman's nonparametric rank correlation coefficient with the probability of significance as the superscript (NS $=$ not significant). ditions of May 1985 and the resulting correlation of pressure bomb readings with relative susceptibility to Leucostoma spp. should be examined in more detail under controlled conditions. Although the concept of predisposition is well understood, an alternative concept for explaining inhibition of pathogens due to influence of environmental factors on trees has never been developed. Other researchers have shown that establishment of pathogens in tree bark is decreased when bark moisture is limiting (Biggs et al., 1983; Tippett and Hill, 1983; Tippett et al., 1987).

\section{Literature Cited}

Bertrand, P.F., H. English, K. Uriu, and F.J. Schick. 1976. Late season water deficits and development of Cytospora canker in French prune. Phytopathology 66:1318-1320.

Biggs, A.R. 1989a. Temporal changes in the infection court after wounding of peach bark and their association with cultivar variation in infection by Leucostoma persoonii. Phytopathology 89627630.

Biggs, A.R. 1989b. Integrated approach to control leucostoma canker of peach in Ontario. Plant Dis. 73:869-874.

Biggs, A.R. and R.A. Cline. 1986. Influence of irrigation on wound response in peach bark. Can. J. Plant Pathol. 8:405-408.

Biggs, A.R., D.D. Davis, and W. Merrill. 1983. Stage of growth and restriction of wound-associated infections in Populus. Can. J. Plant Pathol. 5:269-272.

Biggs, A.R. and N.W. Miles. 1988. Association of suberin formation in uninoculated wounds with susceptibility to Leucostoma cincta and L .persoonii in various peach cultivars. Phytopathology 78:10701074.

Biggs, A.R., N.W. Miles, and R.L. Bell. 1992. Heritability of suberin accumulation in wounded peach bark. Phytopathology 82:83-86.

Scorza, R. 1982. Resistance to Cytospora in stone fruit trees, p. 34-43. In: Proc. Stone Fruit Decline Workshop, Michigan State Univ., East Lansing.

Steel, R.G.D. and J.H. Torrie. 1980. Principles and procedures of statistics. 2nd ed. McGraw-Hill, New York.

Tippett, J.T., D.S. Crombie, and T.C. Hill. 1987. Effect of phloem water. potential on the growth of Phytophthora cinnamomi in Eucalyptus marginata. Phytopathology 77:246-250.

Tippett, J.T. and T.C. Hill. 1983. The relationship between bark moisture and invasion of Eucalyptus marginata by Phytophthora cinnamomi. , Australasian Plant Pathol. 12:40-41.

Weaver, G.M. 1963. A relationship between the rate of leaf abscission and perennial canker in peach varieties. Can. J. Plant Sci. 46:257-264.

Willison, R.S. 1936. Peach canker investigations. II. Infection studies. Can. J. Res. Sect. C 14:27-44. 